\title{
特集「超伝導材料の高性能化 一組織制御技術の進展一」によせて
}

\author{
企画世話人 熊 倉 浩 明* 松 本 要**
}

超伝導は MRI などで既に実用化され，また JR 東海が開発を進めている磁気浮上列車では， これを支える基盤技術となっていることなど，実用上大変重要な技術である. 超伝導は抵抗ゼ口 で大電流を流すことが出来るため, 各種の電力機器に応用するとエネルギー効率が高まるだけで はなく, 機器が小型・軽量化されるので, 特に省エネルギーや低炭素化などの観点から有望視さ れている．このような電力応用の観点から超伝導材料における最も重要な特性は，抵抗ゼロの状 態で流せる超伝導電流の上限值の大きさ(臨界電流密度)である。この臨界電流密度は超伝導体の 微細組織に大きく依存するために，材料の組織制御が極めて重要々なる．本誌では，以上の観点 からこれまでに数回の超伝導特集号を企画・掲載してきており，近年では 2010 年 7 月に特集号 を掲載している，その後，超伝導材料の組織制御による臨界電流特性の改善は，様々な超伝導材 料で大きく進んできており，いくつかの高温超伝導材料においては実用レベルの特性が得られつ つあって，その実用化が真剣に議論される段階にきている。一方，新しい超伝導材料では， 2008 年に発見された鉄系超伝導体が注目されるが，これについても早くから応用を志向した線 材や薄膜の作製が試みられており, 最近では組織制御による臨界電流特性の改善で進歩がみられ る.

このような状況を踏をえて，超伝導材料の組織制御に関する現状を把握するとともに，問題点 を明らかにして今後の研究開発の方向性を考察するために，ここに改めて超伝導特集号を企画す ることとし，広く論文を募集した。 その結果，最新動向を概観したレビューならびにオーバービ ユ一論文 3 編と学術論文 12 編のあわせて 15 編の投稿があり，厳正なる校閲を経て 15 編全てが 掲載されることとなった。これらの論文の内訳をみると, ビスマス系高温酸化物が 1 件, 希土 類系高温酸化物が 6 件， $\mathrm{MgB}_{2}$ が 3 件，鉄系が 2 件，従来の金属系が 2 件で，さらに高温酸化物 と金属系にまたがる機械的特性の論文が 1 件含まれている．希土類系が多いのは，最近の希土 類系線材の活発な研究開発を反映したものであろう． $\mathrm{MgB}_{2}$ では，簡便な手法による特性の向上 に力点が置かれている．また，鉄系に扔いては新しい線材化法が試みられて抢り興味深い。さら に従来の金属系超伝導線材である $\mathrm{Nb}_{3} \mathrm{Sn}$ 線材についても新しい研究があって注目に值する.

超伝導の応用には様々な技術課題が存在し，本特集号掲載の論文は，広範な技術分野のごく一 部をカバーしているにすぎないが，超伝導材料の組織制御は，何れの応用においても核心となる 技術であって最も重要である。これらの論文によって, 特に若い世代の超伝導材料の組織制御に 関する理解が深まり，新たなるブレークスルーが生まれるきっかけになれば幸いである.

最後に，本特集号の発刊に際し，本企画の趣旨にご賛同いただいて最新の興味深い論文をご投 稿いただいた著者の方々，また厳正な校閲を賜った校閲者各位，そして一連の校閲と編集作業に 際してきめ細かく対応してくださいました編集スタッフの方々に，厚く御礼申し上げます.

(2016 年 4 月 27 日受付)

[doi:10.2320/jinstmet.JPR2016901]

\footnotetext{
* 国立研究開発法人物質・材料研究機構＼cjkstart高温超伝導線材グループ(テ305-0047 つくば市千現 1-2-1)

** 九州工業大学大学院工学研究院物質工学専攻 (T804-8550 北九州市戸畑区仙水町 1 番 1 号)

"High Performance Superconducting Materials - Progress of Microstructure Control"; *Hiroaki Kumakura (High$T_{\mathrm{c}}$ superconducting Wires Group, National Institute for Materials Science, 1-2-1, Sengen, Tsukuba, Ibaraki 3050047) and **Kaname Matsumoto (Faculty of Engineering, Kyushu Institute of Technology, 1-1 Sensui-cho, Tobata-ku, Kitakyushu, Fukuoka 804-8550)

Keywords: superconducting materials, microstructure, high temperature oxide superconductor, intermetallic compound superconductor, iron-based superconductor, Superconducting wire, superconducting bulk
} 